\title{
Duchenne muscular dystrophy in Wales: impact of DNA linkage analysis and cDNA deletion screening
}

\author{
A M NORMAN, M UPADHYAYA, N S T THOMAS, K ROBERTS, \\ AND P S HARPER \\ From the Institute of Medical Genetics, University of Wales College of Medicine, Heath Park, Cardiff \\ CF4 $4 X N$.
}

SUMmaRY A register of families with Duchenne muscular dystrophy (DMD) has been maintained in Wales since 1973 . Since 1986 we have attempted to refine carrier status, and when necessary offer prenatal diagnosis, for those at significant risk by using intragenic probes. cDNA probes were included from the beginning of 1988 . Thirty-four $(30 \%)$ of the 115 women tested were assigned a risk of carrying the DMD gene of less than $5 \%$. Thirty-three $(29 \%)$ of the women at $5 \%$ or greater risk are now able to have prenatal diagnosis using a molecular deletion; such deletions were detected in $50 \%$ of affected boys. The remaining women could have prenatal diagnosis using a linked intragenic probe with an error rate varying between $0.25 \%$ and $9 \%$. In 19 cases DNA samples from DMD boys who were dead at the time of analysis were used, indicating that it is essential to bank DNA from all males affected by DMD.

We conclude that a large proportion of women at risk of carrying the DMD gene can now be helped by DNA studies.

Research on the Duchenne muscular dystrophy (DMD) locus has been an activity of this department since the discovery of linked DNA markers in 1982. ${ }^{12}$ The value of such markers has been previously reported. ${ }^{3}$ Since then progress in the molecular genetics of DMD has been rapid, with the discovery of intragenic markers in $1985^{45}$ and the cloning of the entire DMD gene in $1987 .^{6}$ Other groups have subsequently reported the application of linkage analysis using intragenic probes for genetic counselling and prenatal diagnosis in families with DMD. ${ }^{7-13}$ We began to use the pERT and XJ series of intragenic probes for deletion screening and refinement of carrier status in 1986, but before all the families had been studied dystrophin cDNA probes became available to us, making screening for deletions in affected males a priority in 1988. We report here how these activities have improved determination of carrier status for women at risk, and have allowed the possibility of prenatal diagnostic tests in many cases.

\section{Methods}

The first 15 years' experience of the DMD register

Received for publication 22 March 1989 Accepted for publication 31 March 1989. for Wales is reported in the previous paper. ${ }^{14}$ When it became clear that DNA analysis would generate a large amount of new data it was decided to transfer all register information, including pedigree, creatine kinase (CK), and DNA data, onto a microcomputer. An IBM PC compatible computer with 640 kilobytes of memory was used. Families were entered with separate code numbers in LIPED compatible ${ }^{15}$ format so that risk analysis using the MLINK program ${ }^{16}$ was possible, as well as pedigree plotting, including screen displays, using the PLOT2000 program. ${ }^{17}$ The register now contains in excess of 6000 records.

DNA ANALYSIS

DNA was extracted by standard methods from blood samples collected in EDTA obtained from affected boys and their families since 1982, originally as a research undertaking and later as part of the molecular genetic diagnostic service. ${ }^{18}$ The DNA bank now contains over 1600 DMD related samples, including some from outside Wales. The intragenic probes of the pERT series were the gift of L Kunkel, ${ }^{4}$ and those of the $\mathrm{XJ}$ series were the gift of $R$ Worton. ${ }^{5}$ DNA from relevant members of each family was digested to completion with TaqI, XmnI, EcoRV, PstI, and Bam HI according to manufac- 
turers' instructions, subjected to electrophoresis on $0.7 \%$ agarose gels, then Southern blotted onto nylon membranes (Hybond $\mathrm{N}$, Amersham). The DNA on the membranes was hybridised overnight with probe labelled with phosphorus-32 by the random hexonucleotide primed method. ${ }^{19}$ Posthybridisation washes were carried out at $65^{\circ} \mathrm{C}$ in $2 \times \operatorname{SSC}(0.15 \mathrm{~mol} / 1$ sodium chloride, $0.015 \mathrm{~mol} / \mathrm{l}$ sodium citrate), $0 \cdot 1 \%$ sodium dodecyl sulphate (SDS), increasing the stringency gradually as required to $0 \cdot 1 \times \mathrm{SSC}, 0 \cdot 1 \% \mathrm{SDS}$. Membranes were then exposed to Fuji $x$ ray film at $-70^{\circ} \mathrm{C}$ with intensifying screens for one to seven days. Affected boys and their mothers were usually analysed first to look for deletions and to seek heterozygous and therefore informative probes. We first used the pERT probes consecutively starting with pERT87.15/TaqI and BamHI polymorphisms, as they were the most frequently informative. Details of the probes used are given in table 1 .

DNA probes complementary to the DMD gene product dystrophin were used from the beginning of 1988. They were the gift of $K$ E Davies, ${ }^{20} R$ Worton, ${ }^{21}$ and L Kunkel. ${ }^{6}$ DNA was prepared and hybridisation was performed as above. HindIII digests were also prepared for hybridisation with these probes. We also began to use an intronic probe P20, cloned from a deletion hot spot in the DMD gene, the kind gift of $G$ van Ommen, ${ }^{22}$ which is polymorphic with the MspI and HindIII restriction enzymes.

\section{PATIENTS}

Attempting to perform DNA analysis on all the family members on our register would be a vast undertaking. It is clear from our previous study that low risks based on creatine kinase analysis are largely reliable. ${ }^{14}$ Therefore we concentrated our

TABLE 1 Probes used for assigning carrier status or assessing informativeness for prenatal diagnosis or both.

\begin{tabular}{|c|c|c|c|c|c|}
\hline \multirow[t]{2}{*}{ Probe name } & \multirow[t]{2}{*}{ Enzyme } & \multicolumn{2}{|c|}{ Allele sizes $(k b)$} & \multicolumn{2}{|c|}{ Allele frequency } \\
\hline & & 1 & 2 & 1 & 2 \\
\hline \multirow[t]{2}{*}{ pERT87.1 } & $X m n I$ & $8 \cdot 7$ & $7 \cdot 5$ & 0.69 & $0 \cdot 31$ \\
\hline & EcoRV & $12 \cdot 5$ & $10 \cdot 5$ & 0.70 & 0.30 \\
\hline pERT87.8 & TaqI & $3 \cdot 8$ & $2 \cdot 7 / 1 \cdot 1$ & 0.26 & 0.74 \\
\hline \multirow[t]{3}{*}{ pERT87.15 } & TaqI & $3 \cdot 3$ & $3 \cdot 1$ & 0.33 & 0.67 \\
\hline & BamHI & 9.4 & $7 \cdot 1 / 2 \cdot 3$ & 0.38 & 0.62 \\
\hline & $X m n I$ & $2 \cdot 8$ & $1 \cdot 6 / 1 \cdot 2$ & 0.32 & 0.68 \\
\hline XJ1.1 & TaqI & $3 \cdot 8$ & $3 \cdot 1$ & 0.28 & 0.72 \\
\hline $\mathrm{XJ} 2.3$ & Taql & 6.4 & $7 \cdot 8$ & 0.70 & $0 \cdot 30$ \\
\hline $\mathbf{P} 20$ & $\begin{array}{l}\text { MspI } \\
\text { Hind III }\end{array}$ & & & & \\
\hline cDNA1-3 & Various & & & & \\
\hline cDNA $5 b-7$ & Various & & & & \\
\hline cDNA6-7 & Various & & & & \\
\hline cDNA8 & Various & & & & \\
\hline
\end{tabular}

efforts on those families where women of reproductive age remained at medium or high risk, and only analysed those already at low risk when this was necessary for the analysis of higher risk members of the same family, or when it had been specifically requested.

\section{RISK ANALYSIS}

All laboratory results were entered into the computerised register. Risk calculation using information from pedigree analysis and creatine kinase values as well as DNA marker results was performed using the program RISKDNA, ${ }^{23}$ or MLINK $^{16}$ for complex situations. A recombination frequency of 0.05 was used for all intragenic probes.

\section{Results}

Results for 115 women are given here. Their relationship to the last affected male in the pedigree broken down by previous risk based on CK and pedigree analysis is given in table 2 . Thirty-six women were excluded from this part of the analysis for reasons given in table 3 . The remaining 79 women had their risk confirmed or altered by analysis of linked RFLPs. Fig 1 shows how final risk was dependent on the level of risk based on CK and pedigree data. Fig 2 shows the same data ranked. Thirty-four women were assigned risks of less than $5 \%$ compared to 17 before DNA analysis.

TABLE 2 Relationship of 115 at risk women to the affected male and source of phase estimate, by previous risk.

\begin{tabular}{lcccc}
\hline Relationship & $\begin{array}{l}\text { High } \\
\text { risk }\end{array}$ & $\begin{array}{l}\text { Medium } \\
\text { risk }\end{array}$ & $\begin{array}{l}\text { Low } \\
\text { risk }\end{array}$ & Total \\
\hline Mother & 18 & 3 & 0 & 21 \\
Sister & 33 & 29 & 9 & 71 \\
Other & 4 & 11 & 8 & 23 \\
$\begin{array}{l}\text { Affected, alive } \\
\begin{array}{l}\text { Affected, dead, but } \\
\text { sample banked }\end{array}\end{array}$ & 41 & 21 & 13 & 75 \\
$\begin{array}{l}\text { Affected, died } \\
\quad \text { unsampledt }\end{array}$ & 7 & 11 & 1 & 19 \\
\hline
\end{tabular}

*High risk refers to risk of $50 \%$ or greater, medium risk $5 \%$ or greater but less than $50 \%$, and low risk to less than $5 \%$ risk of carrying DMD gene.

tNormal males or high risk females were used to estimate phase in some cases.

TABLE 3 Reasons for excluding 36 women from risk alteration by linkage analysis.

\begin{tabular}{lr}
\hline Obligate carrier & 11 \\
Mother of isolated case without normal son & 9 \\
$\begin{array}{l}\text { Affected male died unsampled, no other source of phase estimate } \\
\text { Deletion found in affected male relative of woman at high risk }\end{array}$ & 8 \\
$\quad$ before linkage attempted & 4 \\
No informative probe found & 3 \\
Multiple crossovers & 1 \\
Total & 36 \\
\hline
\end{tabular}




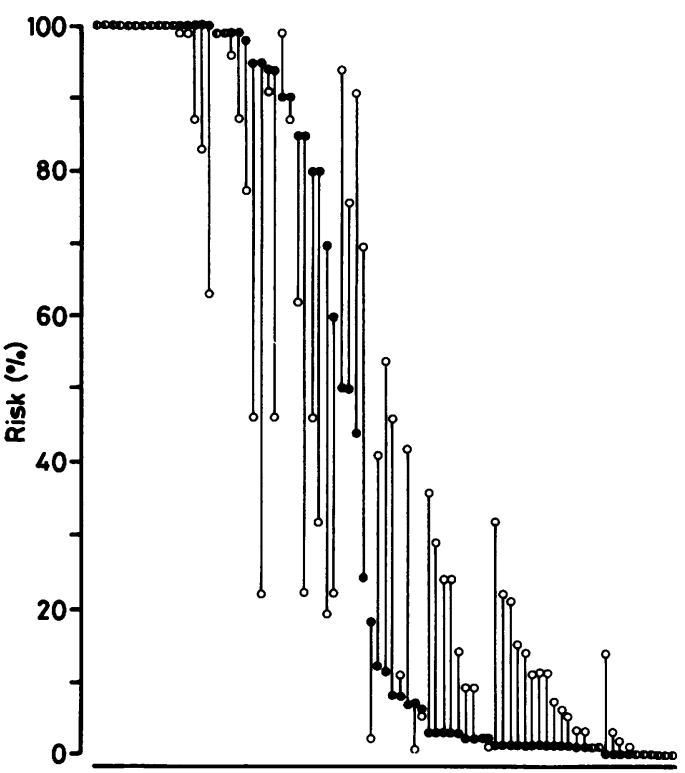

FIG 1 Percentage risks of each woman for whom RFLP analysis was feasible being a carrier of the $D M D$ gene. Open circles represent risk based on $C K$ and pedigree analysis only. Closed circles represent risk after RFLP results have been incorporated. Half shaded circles represent subjects for whom analysis did not change her risk.

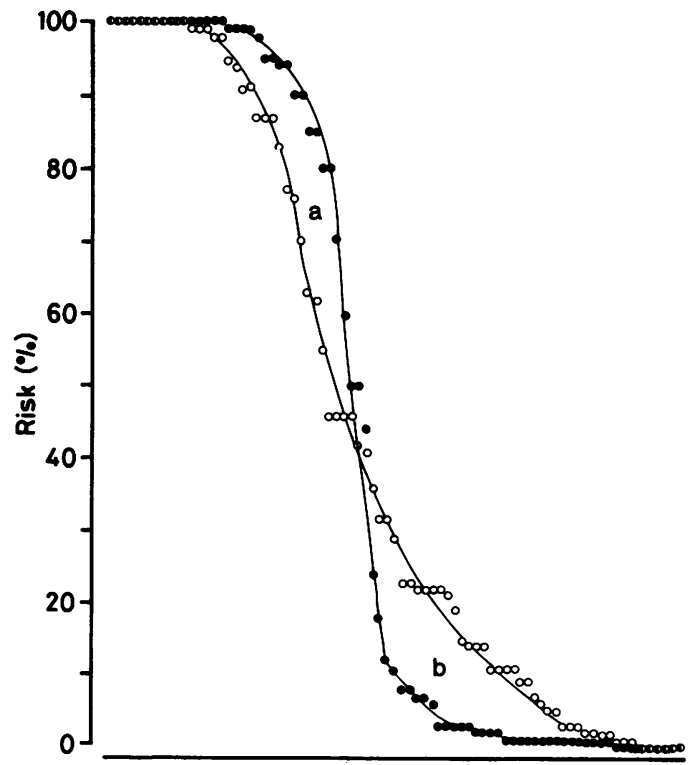

FIG 2 Percentage risks of carrying the DMD gene ranked to show how the distribution of risks has been changed by DNA analysis.
For the 81 women not assigned low risk by this analysis, prenatal diagnosis or exclusion testing may be important. Table 4 shows how many of these women were found to be informative by the use of linked markers and deletion screening. Table 5 summarises the number of women helped by each phase of the analysis. Table 6 gives data on 23 pregnancies where DNA analysis was offered since 1987.

TABLE 4 Informativeness for prenatal diagnosis or exclusion testing in 81 women at $5 \%$ risk or greater of carrying the DMD gene.

\begin{tabular}{llll}
\hline & $\begin{array}{l}\text { cDNA deletion } \\
\text { present in } \\
\text { male relative }\end{array}$ & $\begin{array}{l}\text { cDNA deletion } \\
\text { not present in } \\
\text { male relative }\end{array}$ & $\begin{array}{l}\text { Affected male } \\
\text { relative died } \\
\text { unsampled }\end{array}$ \\
\hline $\begin{array}{l}\text { Informative using RFLP, } \\
\text { low risk allele has 1\% } \\
\text { risk or less }\end{array}$ & 2 & 6 & 5 \\
$\begin{array}{l}\text { Informative using RFLP, } \\
\text { low risk allele has } \\
\text { between 1\% and 4\% risk }\end{array}$ & 3 & 6 & 4 \\
$\begin{array}{l}\text { Informative using RFLP, } \\
\text { low risk allele has 4\% } \\
\text { risk or greater }\end{array}$ & 12 & 21 & 6 \\
$\begin{array}{l}\text { Linkage not done } \\
\text { Total }\end{array}$ & 16 & -33 & -15 \\
\hline
\end{tabular}

TABLE 5 Number (and percentage) of 115 women helped by each stage of DNA analysis.

\begin{tabular}{lll}
\hline $\begin{array}{l}\text { Women assigned low (less than 5\%) } \\
\text { carrier risk on DNA analysis }\end{array}$ & $34 \quad(30 \%)$ \\
$\begin{array}{c}\text { Women in whom prenatal diagnosis using a molecular } \\
\text { deletion possible }\end{array}$ & $33 \quad(29 \%)$ \\
$\begin{array}{c}\text { Women in whom prenatal diagnosis possible with RFLP, } \\
\text { low risk allele has less than 4\% risk }\end{array}$ & $21 \quad(18 \%)$ \\
$\begin{array}{l}\text { Women in whom prenatal diagnosis possible with RFLP, } \\
\text { low risk allele has 4\% risk or greater }\end{array}$ & $27 \quad(23 \%)$ \\
\hline
\end{tabular}

TABLE 6 Outcome of 23 pregnancies in which DNA analysis was offered.

\begin{tabular}{lll}
\hline & $\begin{array}{l}\text { Women at carrier } \\
\text { risk of less } \\
\text { than 5\% }\end{array}$ & $\begin{array}{l}\text { Women at carrier } \\
\text { risk of 5\% or } \\
\text { greater }\end{array}$ \\
\hline Pregnancies & 6 & 17 \\
No prenatal test & 5 & 3 \\
Female & 3 & 1 \\
Male unaffected & 2 & 0 \\
Male affected & 0 & 2 \\
Chorionic villus sampling & 1 & 14 \\
Sexing only* & 0 & 3 \\
Female & 0 & 1 \\
Male terminated & 0 & 2 \\
PND on linkage & 0 & 9 \\
Female & 0 & 5 \\
Low risk male & 0 & $2 \dagger$ \\
High risk male terminated & 0 & 2 \\
PND on deletion & 1 & 2 \\
Female & 1 & 1 \\
Unaffected male & 0 & 1 \\
Affected male terminated & 0 & 0 \\
\hline
\end{tabular}

* One male fetus terminated before DNA analysis available. Two other women found informative subsequently.

tOne low risk male fetus terminated on other grounds.

PND=prenatal diagnosis. 


\section{CASE. HISTORIES}

To show how these techniques have helped some subjects and families, and to illustrate some of the pitfalls, case histories are set out in detail below. The relevant pedigrees appear in fig 3 .

In family D129 III.1, who had a CK based risk of $12 \%$, became pregnant in 1984 when only fetal sexing was available; she had a daughter after chorionic villus sampling (CVS). III.6, who had a CK based risk of $75 \%$, became pregnant in 1987 . DNA analysis could not reliably alter her risk because her grandfather died unsampled, but prenatal exclusion testing would have been possible; however, CVS showed a female fetus. III.4, with a CK based risk of $32 \%$, became pregnant later the same year, but now a deletion detectable with cDNA 1-3 had been discovered in the affected male cousin; again the fetus was female. III.8 had inherited the same pERT87.1/EcoRV allele from her mother as that inherited by her affected brother III.11 and had a $98 \%$ chance of being a carrier. After CVS in 1988 we were able to show that her male fetus had not inherited the deletion and so she continued with the pregnancy.

In family D53 sisters II. 1 and II. 3 had each been given a $22 \%$ risk on $\mathrm{CK}$ and pedigree analysis. II.1 had two pregnancies tested for fetal sex only, terminating a male fetus in her first pregnancy and producing a girl in the second. DNA analysis showed that she had inherited the opposite pERT87.15/Taq allele from her mother to that inherited by her dead affected brother, reducing her risk to $1 \%$. In her third pregnancy no test was undertaken and the resulting son had normal CK at three months of age. II.3 had a $95 \%$ risk after DNA analysis. No probe informative for prenatal diagnosis was found in her first pregnancy and she terminated a male fetus after CVS. Before her next pregnancy she was found to be heterozygous for P20/Msp, but the male fetus inherited the high risk allele and was terminated.

In family D46 the female II.2 had been given a $22 \%$ risk on CK analysis. In her first pregnancy CVS showed a female fetus which subsequently spontaneously aborted. She opted to have amniocentesis in her second pregnancy, but meanwhile a deletion had been found with pERT87.8/Taq in her dead affected brother II.4 (subsequently confirmed with pERT87.1/Xmn, 87.15/Bam, and cDNA 1-3). This deletion was found also in her male fetus which was terminated at 22 weeks. This proved her to be an obligate carrier, but nevertheless she declined testing of her third pregnancy which produced a boy whose CK at five months of age was 8210 IU/l. Duchenne muscular dystrophy was confirmed by showing the familial deletion in his DNA. Meanwhile she had become pregnant for a fourth time. CVS yielded only enough tissue for fetal sexing and

a

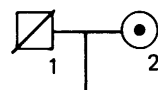

D129
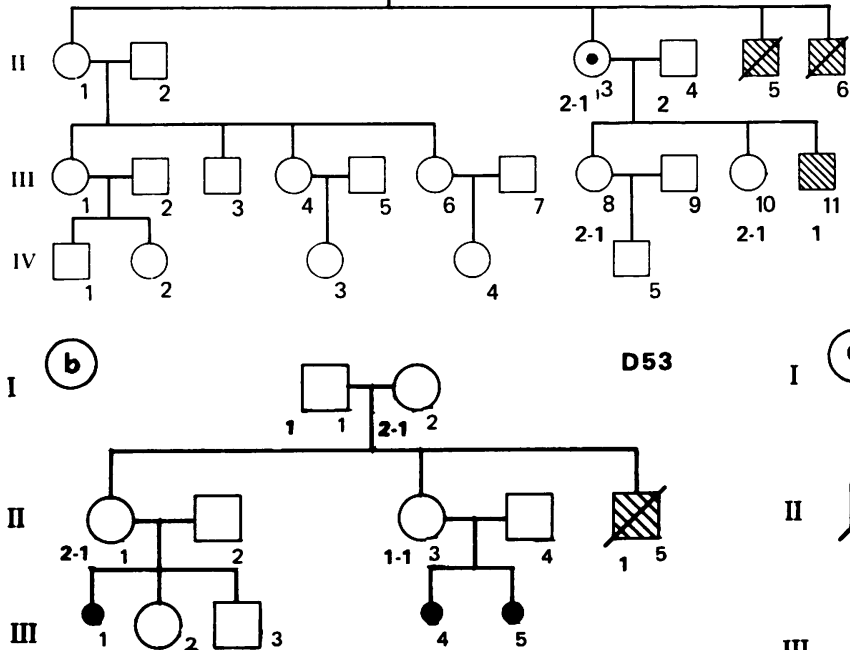

D53

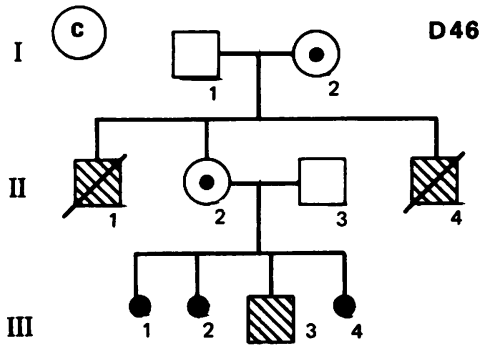

FIG 3 Pedigree of three illustrative families. Probe data are explained in text. 
culture for DNA analysis. She did not wish to risk termination of pregnancy after 13 weeks and so terminated the male fetus at 12 weeks.

\section{Discussion}

This analysis of 115 women of reproductive age at risk of carrying the DMD gene has been of major importance in clarifying their risk status. For 34 women $(30 \%)$ we were able to assign low risk (table 5) and this represented a doubling of the number at low risk, the majority of these now having risks of $1 \%$ or less (fig 1$)$. The $81(70 \%)$ remaining women could all consider prenatal diagnosis with varying degrees of confidence (tables 4 and 5). Thirty-three $(29 \%)$ could have prenatal diagnosis based on the presence of a deletion in an affected male relative. Twenty-one $(18 \%)$ could have prenatal diagnosis or exclusion testing based on linked DNA markers with an error rate of less than $4 \%$, and in the remaining $27(23 \%)$ the error rate would be $4 \%$ or more. The term 'error rate' in this context refers to the risk that a male fetus inheriting the low risk allele will in fact be affected. Strictly speaking the risk of a male fetus inheriting the high risk allele and being unaffected should also be considered, but in practice this cannot be accurately measured because these males are usually terminated. Using a deletion for prenatal diagnosis is likely to reduce both types of error.

DNA analysis improves the discrimination between carriers and non-carriers as shown in fig 2 . The curve based on DNA results has a steeper slope than the CK based curve and approximates more closely to the ideal step graph. The risk for the group as a whole is not altered, and it can be seen that the areas between the curves marked $a$ and $b$ are approximately equal. Creatine kinase analysis thus remains useful and should continue to be used in conjunction with DNA analysis for three reasons. Firstly, it is a good discriminator when used with pedigree analysis, especially for women at low prior risk. ${ }^{14}$ Secondly, DNA based risks are still dependent on the creatinine kinase values of the mother of the affected boy in isolated case pedigrees. Thirdly, it provides a valuable check against recombination, as it is probable that some of the subjects in the middle of fig 1 , whose high (or low) risks based on CK were altered towards the $50 \%$ level by DNA analysis, were recombinants. When recombination occurs between RFLPs precise calculation of risk is not possible. ${ }^{24}$ In such cases we have offered prenatal diagnosis to all those at significant risk. There has also been a progressive change of strategy: women who are already at high risk on $\mathrm{CK}$ and pedigree analysis are unlikely to have their risk changed much by linkage analysis (fig 1), as has also been reported by others. ${ }^{11}$ In such women, searching for a deletion in the affected male therefore takes priority over linkage analysis.

In 19 cases we were able to use DNA samples from affected males who were dead at the time of analysis to alter risks or provide prenatal diagnosis for female relatives. There were six women at high risk in whom a prenatal exclusion test with a $4 \%$ or greater error rate cannot be improved on because the affected male died unsampled, sometimes many years before DNA banking became available. Banking of DNA from all affected males currently alive is essential to reduce this problem in future, and has been an integral part of our programme since molecular approaches were introduced.

cDNA deletions were detected in $50 \%$ of affected males in this series (tables 1 and 4) and this is similar to results from other series. ${ }^{19}{ }^{25-27}$ Twenty-one women from families without a deletion still require prenatal diagnosis, but would have to rely on linked markers with $4 \%$ or greater error rate. The situation is particularly unfavourable for mothers of isolated cases who have no other son to allow detection of phase. It is likely that many of these will rely on fetal sexing, or await improvements in molecular techniques that will allow detection of the DMD mutation in all affected boys.

Throughout this and the accompanying paper we have arbitrarily described risks of less than $5 \%$ as low. This is certainly not the perception of all women in this risk group and one has already requested prenatal diagnosis based on a deletion (table 6). Prenatal deletion testing may have more general application in low risk pregnancies; since an abnormal result is unlikely, and since normal fetuses will not be terminated unlike the situation when linked markers are used, such a test could be done primarily for reassurance. Caution is needed before applying this strategy widely because the main complications of CVS, namely failure to obtain a sample and increased miscarriage risk, ${ }^{28}$ become proportionally more important. Conversely, one obligate carrier has opted to take prenatal diagnosis with linked markers at a $5 \%$ 'error rate'. The resulting boy had normal creatine kinase values at three months. It is unwise to categorise women by magnitude of risk only, since attitudes to risk vary widely between women; this has been the subject of a separate survey. ${ }^{29}$

It is too soon to validate DNA based carrier risks by scoring pregnancy outcome as in the previous paper. Table 6 and the illustrative case histories above show that many women have been helped by DNA analysis. Nevertheless, when any new technique is introduced there will be some who will lose 
rather than gain and it is clear that the woman in family D46 has been very unfortunate. We have attempted to ensure that the results of DNA analysis have been available before pregnancy is undertaken whenever possible. This undoubtedly makes counselling easier as well as saving laboratory time. A deletion or RFLP informative for prenatal diagnosis can now almost always be found if there is sufficient time. Many girls on our register are currently too young to reproduce, but DNA samples from the relevant family members are already banked, in particular from affected males. We have a policy of obtaining blood samples for CK analysis at the age of 15 and performing DNA analysis at the same time. This allows us to offer definitive risk estimation and counselling before pregnancy is undertaken in most cases.

We have shown in the accompanying paper how recurrence of DMD in a family has often happened before diagnosis was made in the first case. As there is no curative treatment for DMD it has traditionally been considered an unsuitable disease for newborn screening, while selective screening of infants with delayed motor development has not proved fully effective.$^{30}$ However, now that carrier testing and prenatal diagnosis of DMD are firmly established, the desirability of newborn screening for all males should be reconsidered. Effective detection and counselling of such families should reduce the recurrence of DMD still further.

We thank K E Davies (Oxford), R Worton (Toronto, Canada), L M Kunkel (Boston, USA), and G van Ommen (Leiden, The Netherlands) for the generous donation of probes. We are also grateful for the support of the Muscular Dystrophy Group of Great Britain and the Muscular Dystrophy Association of America.

\footnotetext{
References

' Murray JM, Davies KE, Harper PS, Meredith L, Mueller CR, Williamson $R$. Linkage relationship of a cloned DNA sequence of the short arm of the $\mathrm{X}$ chromosome to Duchenne muscular dystrophy. Nature 1982;300:69-71.

2 Brown CS, Thomas NST, Sarfarazi M, et al. Genetic linkage relationships of seven DNA probes with Duchenne and Becker muscular dystrophy. Hum Genet 1985;71:62-74.

3 Williams H, Sarfarazi M, Brown C, Thomas N, Harper PS. The use of flanking markers in prediction for Duchenne muscular dystrophy. Arch Dis Child 1986;61:218-22.

+ Monaco AP, Bertelson CJ, Middlesworth W, et al. Detection of deletions spanning the Duchenne muscular dystrophy locus using a tightly linked DNA segment. Nature 1985;316:842-5.

5 Ray PN, Belfall B, Duff C, et al. Cloning of the breakpoint on an $X: 21$ translocation associated with Duchenne muscular dystrophy. Nature 1985;318:671-5.

- Koenig M, Hoffman EP, Bertelson CJ, Monaco AP, Feener C,
}

Kunkel LM. Complete cloning of the Duchenne muscular dystrophy (DMD) cDNA and preliminary genomic organization of the DMD gene in normal and affected individuals. Cell 1987;50:509-17.

7 Read AP, Kerzin-Storrar L, Mountford RC, Elles RG, Harris R. A register based system for gene tracking in Duchenne muscular dystrophy. J Med Genet 1986;23:581-6.

8 Bakker E, Bonten EJ, de Lange LF, et al. DNA probe analysis for carrier detection and prenatal diagnosis of Duchenne muscular dystrophy: a standard diagnostic procedure. J Med Genet 1986;23:573-80.

9 Old JM, Davies KE. Prenatal diagnosis of Duchenne muscular dystrophy by DNA analysis. J Med Genet 1986;23:556-9.

10 Darras BT, Harper JF, Francke U. Prenatal diagnosis and detection of carriers with DNA probes in Duchenne's muscular dystrophy. N Engl J Med 1987;316:985-92.

11 Hodgson S, Walker A, Cole C, et al. The application of linkage analysis to genetic counselling in families with Duchenne or Becker muscular dystrophy. J Med Genet 1987;24:152-9.

12 Goodship J, Malcolm S, Robertson ME, Pembrey ME, Service experience using DNA analysis for genetic prediction in Duchenne muscular dystrophy. J Med Genet 1988;25:14-19.

13 Cole CG, Walker A, Coyne A, et al. Prenatal testing for Duchenne and Becker muscular dystrophy. Lancet 1988;i: 262-5.

14 Norman AM, Rogers C, Sibert JR, Harper PS. Duchenne muscular dystrophy in Wales: a 15 year study, 1971-1986. J Med Genet 1989;26:560-4.

$15 \mathrm{Ott} \mathrm{J}$. Estimation of the recombination fraction in human pedigrees: efficient computation of the likelihood for human linkage studies. Am J Hum Genet 1974;26:588-9.

16 Lathrop GM, Lalouel JM, Julier C, Ott J. Strategies for multilocus linkage analysis in humans. Proc Natl Acad Sci USA 1984;81:3443-6.

17 Wolak G, Sarfarazi M. PLOT 2000: a universal pedigree plotting programme. Institute of Medical Genetics, Cardiff, 1988.

18 Meredith AL, Upadhyaya M, Harper PS. Molecular genetics in clinical practice: evolution of a DNA diagnostic service. $\mathrm{Br}$ Med J 1988;297:843-6.

19 Feinberg AP, Vogelstein B. A techique for radiolabelling DNA restriction endonuclease fragments to high specific activity. Anal Biochem 1983;132:6-13.

20 Forrest SM, Cross GS, Speer A, Gardner-Medwin D, Burn J, Davies KE. Preferential deletion of exons in Duchenne and Becker muscular dystrophies. Nature 1987;329:638-40.

21 Burghes AHM, Logan C, Hu X, Belfall B, Worton R, Ray PN. A cDNA clone from the Duchenne/Becker muscular dystrophy gene. Nature 1987;328:434-7.

22 Wapenaar MC, Kievits T, Hart KA, et al. A deletion hot spot in the Duchenne muscular dystrophy gene. Genomics 1988;80: 152-6.

23 Sarfarazi $M$, Williams $H$. A computer programme for estimation of genetic risk in $\mathrm{X}$ linked disorders, combining pedigree and DNA probe data with other conditional information. $J$ Med Genet 1986;23:40-5.

${ }^{24}$ Edwards JH. The population genetics of Duchenne: natural and artificial selection in Duchenne muscular dystrophy. $J$ Med Genet 1986;23:521-30.

25 Forrest SM, Cross GS, Thomas NST, et al. Effective strategy for prenatal prediction of Duchenne and Becker muscular dystrophy. Lancet 1987;ii:1294-7.

26 Read AP, Mountford RC, Forrest SM, Kenwrick SJ, Davies KE, Harris R. Patterns of exon deletions in Duchenne and Becker muscular dystrophy. Hum Genet 1988;80:152-6.

27 Darras BT, Blattner P, Harper JF, Spiro AJ, Alter S, Francke $\mathrm{U}$. Intragenic deletions in 21 Duchenne muscular dystrophy (DMD)/Becker muscular dystrophy (BMD) families studied with the dystrophin cDNA: location of breakpoints on HindIII and Bg1II exon-containing fragment maps, meiotic and mitotic origin of the mutations. Am J Hum Genet 1988;43:620-9. 
${ }^{28}$ Canadian collaborative CVS-amniocentesis clinical trial group. Multicentre randomised clinical trial of chorionic villus sampling and amniocentesis. Lancet 1989;i:1-6.

${ }^{29}$ Parsons E. Living with Duchenne muscular dystrophy: mothers' and daughters' experiences and definitions of handicap and risk. $\mathrm{PhD}$ thesis, University of Wales College of Medicine, Cardiff, 1989.

30 Smith RA, Rogers M, Bradley DM, Sibert JR, Harper PS.
Screening for Duchenne muscular dystrophy. Arch Dis Child (in press).

Correspondence to Dr A M Norman, Institute of Medical Genetics, University Hospital of Wales, Heath Park, Cardiff CF4 4XN. 